Article available at nttp://Www.parasite-journal.org or nttp://dx.dol.org/10.1051/parasite/2003101p51

\title{
Coccidiosis of the wild rabitt (Oryctolagus cuniculus) in France
}

\author{
GRÈS V.*, VOZA T.*, CHABAUD A.* \& LANDAU I.*
}

\section{Summary :}

In 1998-1999 a survey of coccidiosis in wild rabbits was carried out in six different localities in France. About five individuals were caught monthly in each locality and a total of 254 wild rabbits was examined. Ten species of Coccidia were identified: Eimeria perforans, E. flavescens, E. piriformis, E. exigua, E. media, E. magna, E. coecicola, E. stiedai, E. roobroucki, E. intestinalis. Intensity of infection in young individuals was higher than in adults. Intensity was highest in winter but, as there are no young rabbits in winter, in young individuals it was higher in spring and autumn than in summer. Intensities were higher in the northern rather than in southern localities. Ranking of prevalence was remarkably stable, in contrast to the variability of the parasitic load. The equilibrium between congeneric species of rabbit coccidia (stable prevalence rank, variable parasitic load) is thought to be probably the consequence of the opportunistic feeding habits of rabbits

KEY WORDS : Eimeria, wild rabbit, congeneric species.
Résumé : LA COCCIDIOSE DU LAPIN DE GARENNE (ORYCTOLAGUS CUNICULUS) EN FRANCE

En 1998-1999, nous avons mené une étude sur la coccidiose du lapin de garenne dans six localités différentes en France. Pour chaque site, cinq individus environ ont été capturés mensuellement et un total de 254 lapins a été examiné. Dix espèces de Coccidies ont pu être identifiées: Eimeria perforans, E. flavescens, E. piriformis, E. exigua, E. media, E. magna, E. coecicola, E. stiedai, E. roobroucki, E. intestinalis. Chez les jeunes lapins, l'intensité de l'infection apparaît plus élevée que chez les adultes. C'est en hiver que l'intensité de l'infection des adultes est la plus élevée. Par contre, chez les juvéniles, qui n'apparaissent qu'au printemps, l'infection est plus importante au printemps et à l'automne qu'en été. Les sites du nord présentent les intensités les plus élevées. L'ordre des prévalences apparait remarquablement stable comparé à la variabilité de la charge parasitaire. L'équilibre entre les espèces congénériques de coccidies de lapins lordre des prévalences stable, charge parasitaire variable) pourrait être la conséquence du comportement alimentaire opportuniste du lapin de garenne.

MOTS CLÉS : Eimeria, lapin de garenne, espèces congénériques.

\section{INTRODUCTION}

$\mathrm{R}$ abbit Eimeria have been extensively used as experimental models, because of the small size of their host, its great fecundity and economic importance. Information on this group of parasites is exceptionally extensive and precise (Coudert et al., 1995), but it mainly concerns the domestic rabbit. The present work is an attempt to compare the fauna of wild and domestic rabbits and to understand the type of balance achieved between the parasite species. Results were compared with reports from the few other countries were similar surveys were performed.

\footnotetext{
* Muséum National d'Histoire Naturelle, Équipe Parasitologie comparée et modèles expérimentaux associée à l'INSERM, U567 et Laboratoire de Protozoologie et Parasitologie comparée (EPHE), 61, rue Buffon, 75231 Paris Cedex 05, France.

Correspondence: Irène Landau.

Tel.: +33(0)140793500 - Fax: +33(0)140793499.

E-mail: landau(a) cimrs1.mnhn.fr
}

\section{MATERIALS AND METHODS}

\section{STUDY AREAS}

The survey was carried out in six study areas.

Arjuzanx reserve covers 2,452 ha in the south-west of France (department of Landes, $44^{\circ} 00^{\prime} \mathrm{N}, 0^{\circ} 51^{\prime} \mathrm{W}$ ). The climate is oceanic, the mean annual rainfall is $1,016 \mathrm{~mm}$ and the mean annual temperature $12.9^{\circ} \mathrm{C}$. Rabbits were caught in mesophilic land colonised by Ilex europeus, Caluna vulgaris, Erica cinerea and Erica scoparia.

Chèvreloup arboretum occupies 200 ha in Versailles near Paris (department of Yvelines, $48^{\circ} 50^{\prime} \mathrm{N}, 02^{\circ} 06^{\prime} \mathrm{E}$ ). The climate is oceanic with continental influence, the mean annual rainfall is $606 \mathrm{~mm}$ and the mean annual temperature $10.3^{\circ} \mathrm{C}$. The terrain is mesophilic grassland.

Donzère-Mondragon reserve covers 1,545 ha in the south-east of France (departments of Drôme and Vaucluse, $44^{\circ} 26^{\prime} \mathrm{N}, 4^{\circ} 42^{\prime} \mathrm{E}$ ). The climate is mediterranean with continental influence. The mean annual rain- 
fall is $860 \mathrm{~mm}$ and the mean annual temperature $12.8^{\circ} \mathrm{C}$. It is very diversified xerophilic wasteland supporting Graminaceae, Fabaceae and Compositae and some shrubs, mainly Cornus sanguinea, Populus alba, P. nigra, Crataegus monogyna and Robinia pseudacacia.

Massereau reserve covers 393 ha in the west of France (department of Loire-Atlantique $47^{\circ} 14^{\prime} \mathrm{N}, 01^{\circ} 55^{\prime} \mathrm{W}$ ). The climate is oceanic, the mean annual rainfall is $780 \mathrm{~mm}$ and the mean annual temperature $11.7^{\circ} \mathrm{C}$. It comprises mesophilic meadowland with mainly Agrostis sp., Oleus lanatus and Trifolium spp., a canal border with Iris spp, Joncus spp, Phragmites communis and a dam bordering a swamp, with Prunus spinosa and Rubus fructicosus.

Gerstheim reserve has an area of 2,630 ha; it is located in the east of France (department of Bas-Rhin) ( $48^{\circ}$ $\left.22^{\prime} \mathrm{N}, 7^{\circ} 42^{\prime} \mathrm{E}\right)$. The climate is continental, the mean annual rainfall is $650 \mathrm{~mm}$ and the mean annual temperature is $10^{\circ} \mathrm{C}$. The region used for trapping consisted of three artificial sites with small shrubby vegetation of the mesobrometum or mesoxerobrometum type.

Béniguet island reserve has an area of 64 ha and is located three miles off Conquet in Brittany ( $48^{\circ} 21^{\prime} \mathrm{N}$, $\left.04^{\circ} 51^{\prime} \mathrm{W}\right)$. The climate is oceanic, the mean annual rainfall is $800 \mathrm{~mm}$ and the mean annual temperature is $11.8^{\circ} \mathrm{C}$. The terrain comprises xerophilic dunes covered with Armeria maritima, Festuca rubra, Senecio jacobaea, Silenae matitima and Carex arenaria.

It was not possible to evaluate, in the various reserves, the rabbits density per hectare.

\section{SAMPLING}

Five rabbits were usually caught each month from February 1998 to February 1999 in the five mainland areas.

Twenty rabbits were caught on a single occasion in the Béniguet reserve, on the 23 and 24th of September 1998.
Caecal contents were diluted with two volumes of $2.5 \%$ potassium dichromate solution and samples were kept for three days at room temperature of $24^{\circ} \mathrm{C}$, in large Petri dishes to allow maturation of the oocysts. The faecal suspensions were then filtered through sieves of decreasing mesh size $(400 \mu \mathrm{m}, 200 \mu \mathrm{m}, 100 \mu \mathrm{m})$. Oocysts were isolated by magnesium sulphate flotation, identified and counted with the aid of a MacMaster cell. Results are expressed as the number of oocysts per gram of caecal contents. The age of rabbits was evaluated by weighing the crystalline lenses, previously fixed with formaldehyde solution. Rabbits were classified as young (crystalline lenses weighing less than $100 \mathrm{mg}$ ) or adult (crystalline lenses weighing more than $100 \mathrm{mg}$ ) according to Myers \& Gilbert (1968).

Sporulated oocysts were identified according to the published morphological criteria, particularly those of Coudert et al. (1995).

\section{RESULTS}

Ten species were identified: Eimeria perforans (Leuckart, 1879); E. flavescens Marotel \& Guilhon, 1941; E. piriformis Kotlan \& Pôspesch 1934; E. exigua Yakimoff, 1934; E. media Kessel, 1929; E. magna Pérard,1925; E. intestinalis Cheissin, 1948; E. stiedai (Lindemann, 1865); E. coecicola Cheissin, 1947 and E. roobroucki described recently by Grès, Marchandeau \& Landau (2002). No specific hare coccidia were identified.

Detailed figures of prevalence and parasite load have been recorded in a book (LV) deposited in our laboratory (Parasitologie comparée et modèles expérimentaux) at the Muséum National d'Histoire Naturelle in Paris.

The sex of the animals had no impact on infections which varied with the age of the rabbits, the season and the locality.

Tables I to IV and figures 1 to 4 summarize our results. It was not possible to publish here all the detailed

\begin{tabular}{|c|c|c|c|c|c|c|}
\hline & $\begin{array}{c}\text { Arjuzanx } \\
(\mathrm{n}=44)\end{array}$ & $\begin{array}{c}\text { Béniguet } \\
(\mathrm{n}=19)\end{array}$ & $\begin{array}{c}\text { Chèvreloup } \\
(\mathrm{n}=19)\end{array}$ & $\begin{array}{l}\text { Donzère-M. } \\
(\mathrm{n}=53)\end{array}$ & $\begin{array}{l}\text { Massereau } \\
(\mathrm{n}=39)\end{array}$ & $\begin{array}{l}\text { Gerstheim } \\
(\mathrm{n}=43)\end{array}$ \\
\hline E. perforans & $923 \pm 545$ & $189 \pm 73$ & $11,499 \pm 5,449$ & $228 \pm 52$ & $596 \pm 123$ & $2,069 \pm 733$ \\
\hline E. flavescens & $276 \pm 59$ & $221 \pm 62$ & $4,583 \pm 2,246$ & $193 \pm 39$ & $327 \pm 70$ & $1,183 \pm 485$ \\
\hline E. media & $125 \pm 72$ & $270 \pm 146$ & $2,897 \pm 1,423$ & $40 \pm 14$ & $733 \pm 433$ & $1,490 \pm 1,106$ \\
\hline E. exigua & $8 \pm 2$ & $3 \pm 2$ & $1,937 \pm 1,121$ & $5 \pm 3$ & $39 \pm 14$ & $585 \pm 544$ \\
\hline E. piriformis & $70 \pm 20$ & $170 \pm 138$ & $5,596 \pm 2,817$ & $67 \pm 234$ & $56 \pm 20$ & $77 \pm 25$ \\
\hline E. stiedai & $10 \pm 10$ & $7 \pm 5$ & $54 \pm 40$ & $0.4 \pm 0.4$ & $5 \pm 4$ & $6 \pm 6$ \\
\hline E. magna & $1 \pm 0.3$ & $15 \pm 7$ & $84 \pm 65$ & $2 \pm 1$ & $5 \pm 3$ & $10 \pm 5$ \\
\hline E. coecicola & $17 \pm 14$ & $0.4 \pm 0.4$ & $665 \pm 486$ & $11 \pm 6$ & $18 \pm 15$ & $110 \pm 54$ \\
\hline E. intestinalis & 0 & $38 \pm 34$ & $3,151 \pm 2,842$ & 0 & $0.1 \pm 0.1$ & $13 \pm 13$ \\
\hline E. roobroucki & $2 \pm 1$ & $0.7 \pm 0.4$ & 0 & $0.1 \pm 0.1$ & $2 \pm 2$ & $1 \pm 1$ \\
\hline
\end{tabular}

Table I. - Mean parasitic load of adult rabbits according to locality ( \pm standard deviation). 


\begin{tabular}{lcccccc}
\hline & $\begin{array}{c}\text { Arjuzanx } \\
(\mathrm{n}=9)\end{array}$ & $\begin{array}{c}\text { Béniguet } \\
(\mathrm{n}=1)\end{array}$ & $\begin{array}{c}\text { Chèvreloup } \\
(\mathrm{n}=9)\end{array}$ & $\begin{array}{c}\text { Donzère-M. } \\
(\mathrm{n}=7)\end{array}$ & $\begin{array}{c}\text { Massereau } \\
(\mathrm{n}=1)\end{array}$ & $\begin{array}{c}\text { Gerstheim } \\
(\mathrm{n}=10)\end{array}$ \\
\hline E. perforans & $16,840 \pm 7,415$ & 164 & $167,545 \pm 80,793$ & $13,763 \pm 10,370$ & 4,453 & $107,236 \pm 69,381$ \\
E. flavescens & $4,529 \pm 2,390$ & 15 & $76,533 \pm 43,807$ & $3,021 \pm 1,269$ & 4,593 & $43,372 \pm 41,738$ \\
E. media & $19,935 \pm 13,566$ & 0 & $19,885 \pm 16,689$ & $1,350 \pm 1,071$ & 0 & $49,923 \pm 28,414$ \\
E. exigua & $874 \pm 652$ & 0 & $1,988 \pm 1,196$ & $285 \pm 179$ & 0 & $2,512 \pm 2,139$ \\
E. piriformis & $4 \pm 4$ & 140 & $11,121 \pm 6,399$ & $234 \pm 106$ & 0 \\
E. stiedai & $9,575 \pm 9,408$ & 0 & $72,112 \pm 50,966$ & $14,025 \pm 12,621$ & 347 & $45,768 \pm 27,327$ \\
E. magna & $1,785 \pm 1,566$ & 6 & $52,014 \pm 51,483$ & $975 \pm 780$ & 120 & $20,995 \pm 13,265$ \\
E. coecicola & $38 \pm 38$ & 0 & $38,941 \pm 25,536$ & $53 \pm 53$ & 0 & $32,933 \pm 16,055$ \\
E. intestinalis & 0 & 0 & $16,732 \pm 10,810$ & 0 & 0 & 0 \\
E. roobroucki & 0 & 0 & 0 & 0 & 0 & 0 \\
\hline
\end{tabular}

Table II. - Mean parasitic load of juvenile rabbits, according to locality ( \pm standard deviation).

\begin{tabular}{lccrr}
\hline & Spring $(\mathrm{n}=52)$ & Summer $(\mathrm{n}=40)$ & Autumn $(\mathrm{n}=67)$ & Winter $(\mathrm{n}=58)$ \\
\hline E. perforans & $783 \pm 189$ & $493 \pm 230$ & $1,109 \pm 534$ & $4,349 \pm 1,890$ \\
E. flavescens & $293 \pm 48$ & $1,333 \pm 986$ & $775 \pm 267$ & $979 \pm 436$ \\
E. media & $526 \pm 323$ & $139 \pm 97$ & $603 \pm 301$ & $1,503 \pm 889$ \\
E. exigua & $48 \pm 19$ & $26 \pm 14$ & $417 \pm 353$ & $562 \pm 377$ \\
E. piriformis & $102 \pm 37$ & $249 \pm 183$ & $609 \pm 369$ & $1,132 \pm 880$ \\
E. stiedai & $1 \pm 0.6$ & $19 \pm 13$ & $19 \pm 15$ & $5 \pm 5$ \\
E. magna & $5 \pm 3$ & $2 \pm 1$ & $10 \pm 4$ & $28 \pm 22$ \\
E. coecicola & $22 \pm 13$ & $70 \pm 40$ & $46 \pm 37$ & $213 \pm 159$ \\
E. intestinalis & 0 & 0 & $106 \pm 84$ & $932 \pm 932$ \\
E. roobroucki & $3 \pm 2$ & 0 & $0.2 \pm 0.1$ & $0.4 \pm 0.2$ \\
\hline
\end{tabular}

Table III. - Mean parasitic load of adult rabbits according to season ( \pm standard deviation).

\begin{tabular}{lccc}
\hline & Spring $(\mathrm{n}=9)$ & Summer $(\mathrm{n}=18)$ & Autumn $(\mathrm{n}=9)$ \\
\hline E. perforans & $68,597 \pm 27,730$ & $56,232 \pm 37,738$ & $133,554 \pm 85,980$ \\
E. flavescens & $52,333 \pm 44,422$ & $11,118 \pm 8,026$ & $57,250 \pm 45,502$ \\
E. media & $50,211 \pm 28,617$ & $3,239 \pm 1,906$ & $39,447 \pm 23,868$ \\
E. exigua & $4,124 \pm 2,449$ & $448 \pm 332$ & $833 \pm 579$ \\
E. piriformis & $1,796 \pm 1,726$ & $4,075 \pm 3,368$ & $1,353 \pm 658$ \\
E. stiedai & $92,789 \pm 51,533$ & $4,983 \pm 4,698$ & $40,518 \pm 25,431$ \\
E. magna & $8,628 \pm 8,224$ & $34,442 \pm 26,120$ & $385 \pm 196$ \\
E. coecicola & 0 & $18,120 \pm 9,407$ & $39,532 \pm 25,744$ \\
E. intestinalis & 0 & $5,035 \pm 5,035$ & $6,663 \pm 5,677$ \\
E. roobroucki & 0 & 0 & 0 \\
\hline
\end{tabular}

Table IV. - Mean parasitic load of juvenile rabbits according to season ( \pm standard deviation).

tables and graphs. They may however be found in V. Grès thesis (2001):

i) the mean parasite load of adult (Table I) and young (Table II) rabbits from each locality (for all seasons together);

ii) the mean parasite load of adult (Table III) and young (Table IV) rabbits at different seasons;

iii) prevalences of the different species in each study area throughout the year, in adult (Fig. 1) and young (Fig. 2) rabbits; and

iv) prevalences of the different species in adult (Fig. 3) and young (Fig. 4) rabbits according to the season. There were no young rabbits present in winter.

\section{INTENSITY OF INFECTION}

Parasite load was variable in young rabbits, possibly depending on the uncertain chance of their becoming infected

In adult rabbits, intensity of infection was generally highest in winter. In young animals it was higher in spring and autumn than in summer except for E. piriformis and E. magna.

In adult rabbits, the intensity of infection was generally highest in winter.

The principal feature determining the intensity of infection was the geographical location. Parasite load was 


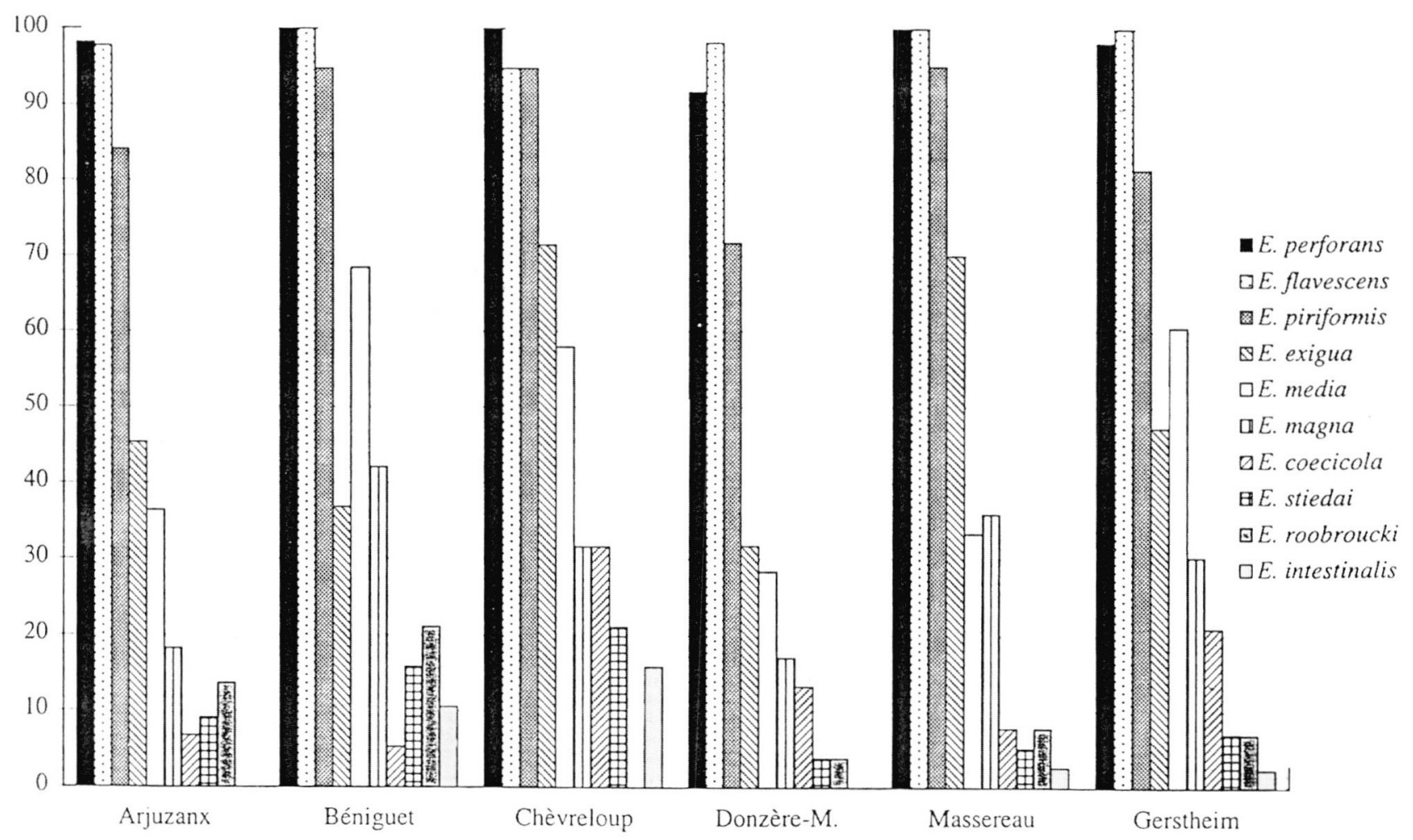

Fig. 1. - Prevalences of the Eimeria species in adult rabbits, according to locality.

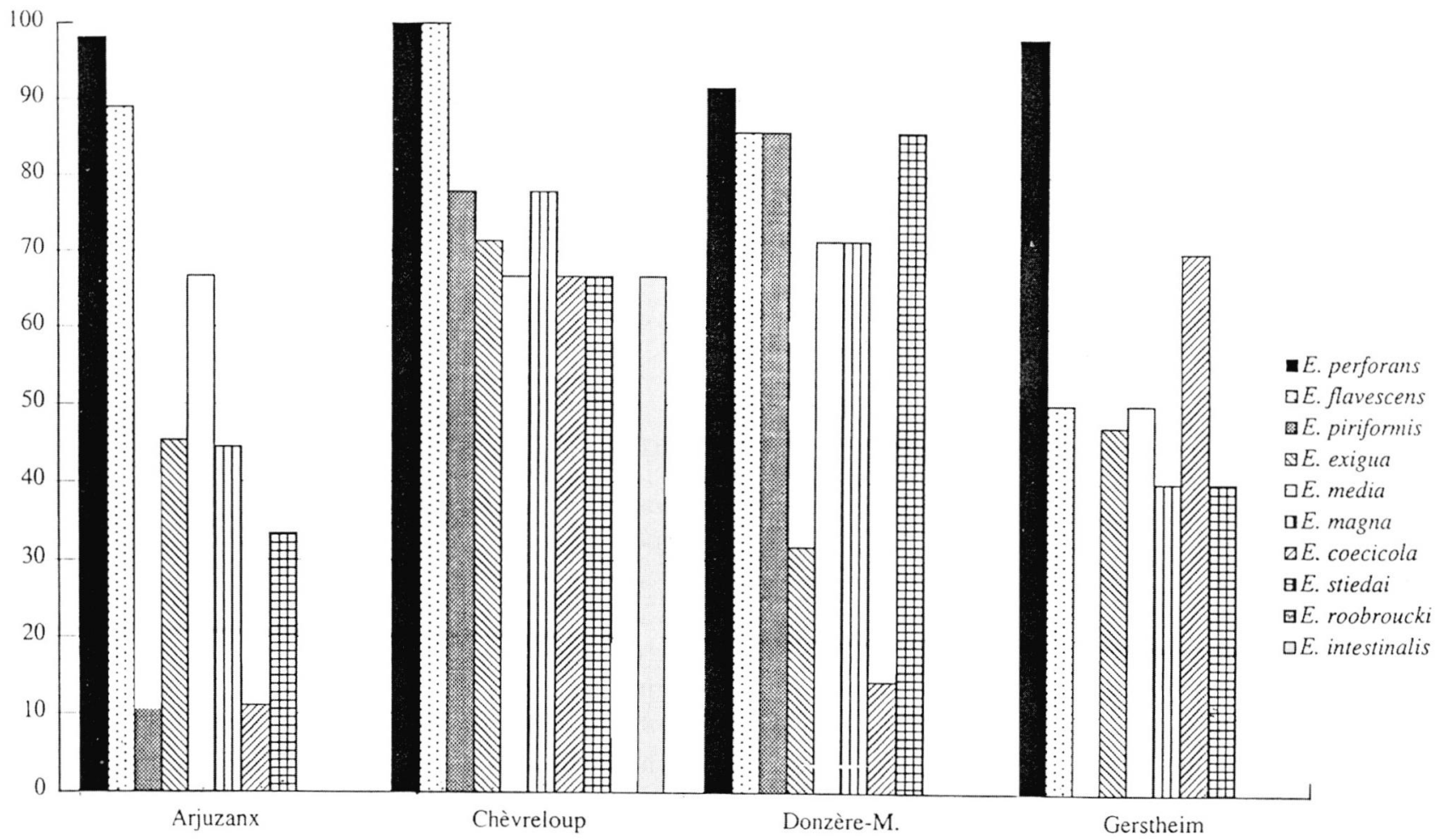

Fig. 2. - Prevalences of the Eimeria species in juvenile rabbits, according to locality. 


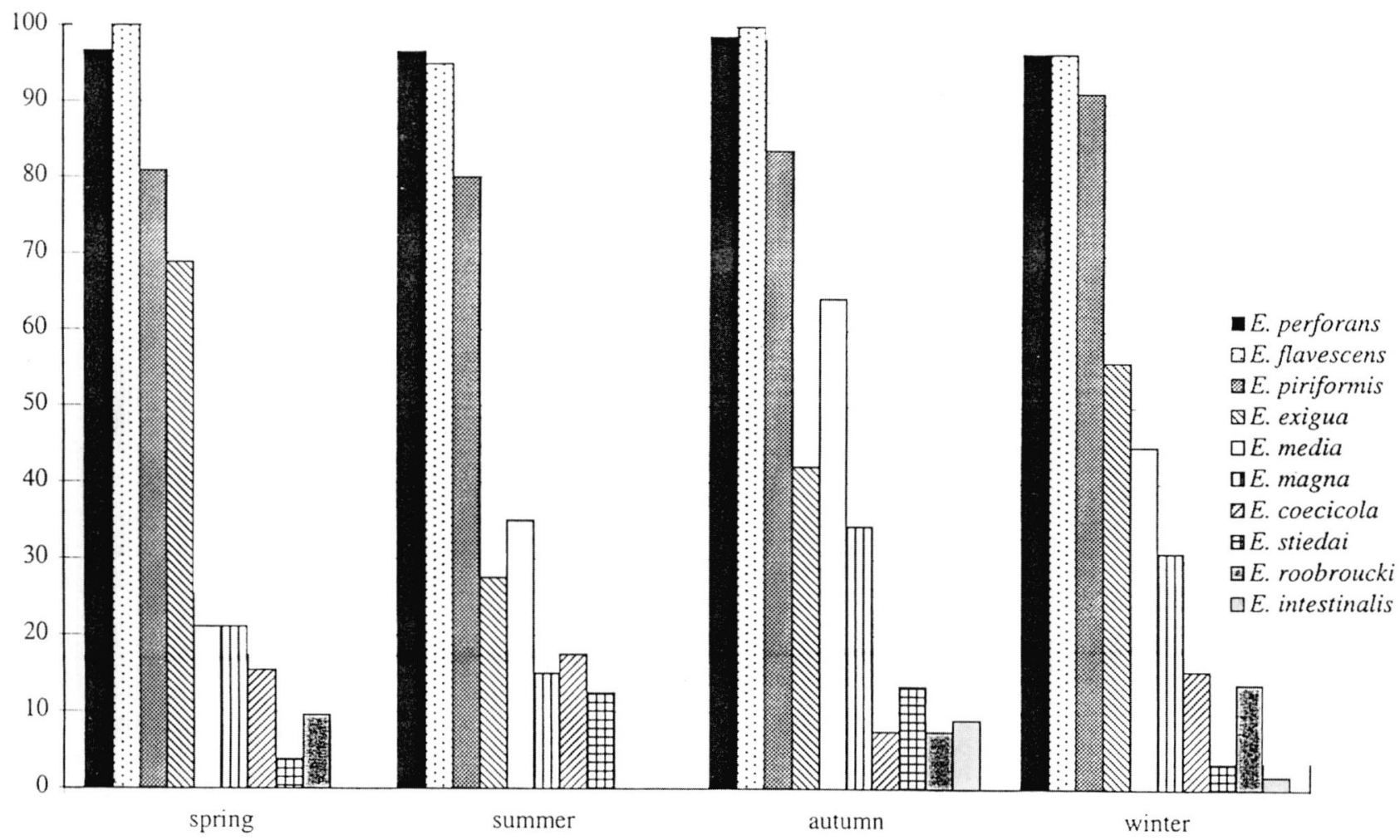

Fig. 3. - Prevalences of Eimeria species in adult rabbits, according to season.

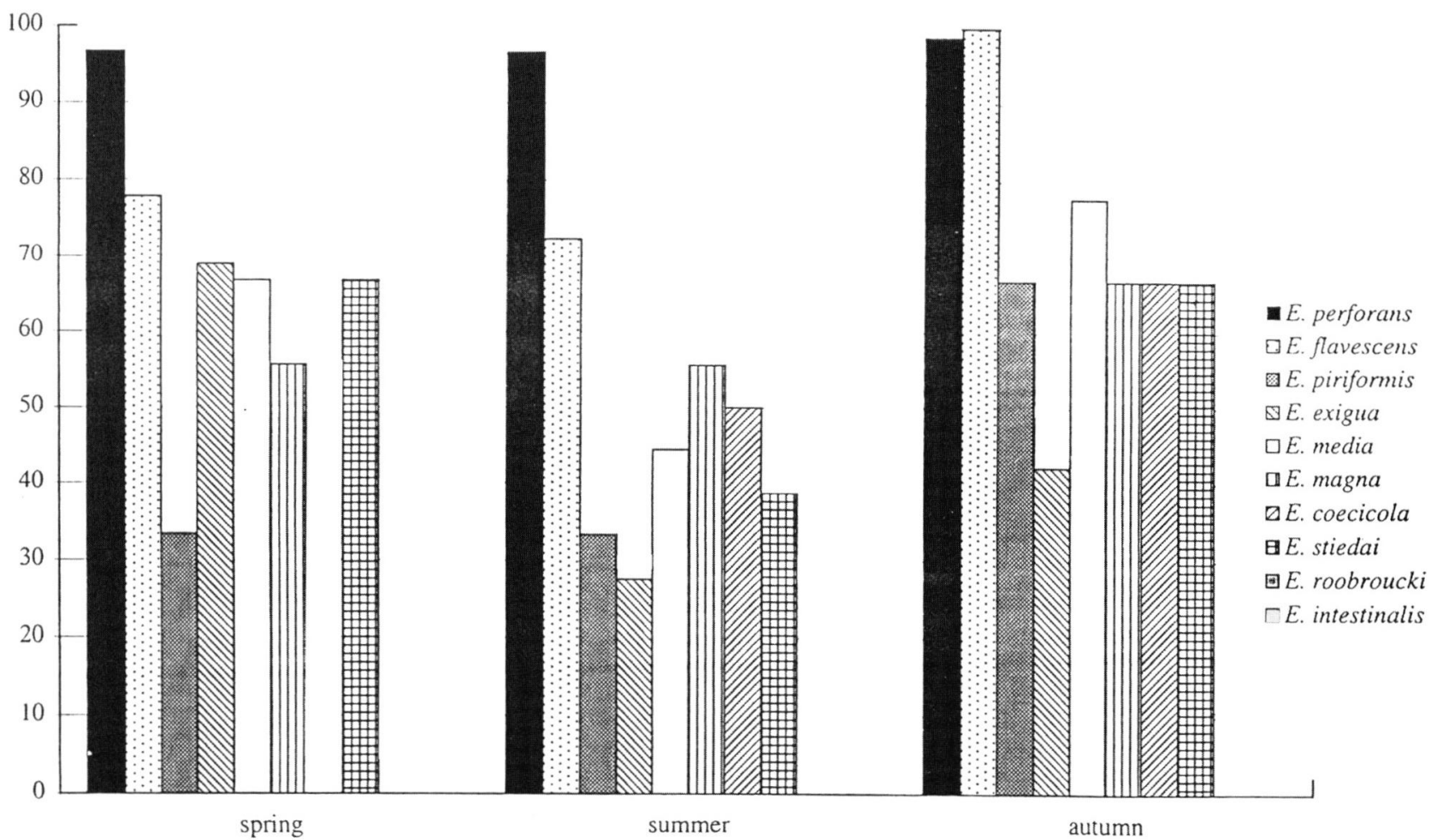

Fig. 4. - Prevalences of Eimeria species in juvenile rabbits, according to season. 
high in the humid and relatively cold localities (Ile de France and Alsace), lower along the Atlantic littoral (Loire and Landes) and lower still in the dryer and warmer areas (Rhône valley).

\section{PREVALENCES}

In adult rabbits, prevalence was highest with two species, E. perforans and E. flavescens; it was moderately high with E. media and E. piriformis, and generally low with the six other species.

Results from young rabbits were available (Figs 2 and 4) from only four locations (seven to 10 rabbits examined from each): Arjuzanx, Chèvreloup, DonzèreMondragon and Gershteim. E. roobrouki was absent and $E$. intestinalis was found only in Chèvreloup.

Prevalences were, with few exceptions, remarkably similar in the different localities: nearly $100 \%$ with $E$. perforans and E. flavescens and $70 \%$ with the six other species. Two exceptions were E. piriformis, absent from Gerstheim, and E. exigua and E. coecicola, which had low prevalences (around 10-30 \%) in Arjuzanx and Donzère-Mondragon.

The histogram of prevalence (Fig. 4) according to season shows least variability in autumn compared with spring and summer, i.e. E. perforans and E. flavescens around $100 \%$ and the six other species around $70 \%$.

With the adult rabbits, in contrast with the variability of parasite load according to location (Fig. 1), we observed stable prevalences: E. perforans and E. flavescens, 90-100 \%; E. piriformis, 70-95 \%; E. exigua, 32-72 \%; E. media, 29-69 \%; E. magna, 17-42\%; E. coecicola, 5-32 \%; E. stiedai, 4-21\%; E. roobrouck, 0-21\%; and E. intestinalis, 0-16\%. Even more striking, in all localities, the ranked order of prevalence of each species was remarkably stable: E. perforans and $E$. flavescens, 1-2; E. piriformis, 3; E. exigua, 4-5 (with low parasite loads); E. media, 4-5; E. magna, 6; E. coecicola and E. stiediai, 7-9; E. roobroucki and E. intestinalis, 9-10.

\section{DISCUSSION}

\section{COMPARISON OF COCCIDIOSIS OF WILD AND DOMESTIC RABBITS}

F or this type of study, precise specific identification is necessary but the systematics of Coccidia are difficult. Congeneric species are frequent with the Nematodes, for example, and their morphology is varied with many differential characters, while with Eimeria the morphology of the oocyst, which is the main criterion is a weak character. Confusion between species is always possible and it is disturbing to find in the literature different biological characters assigned to the same species by reliable authors. In the same way the origin of strains is not always specified, and biological differences observed amongst strains may in fact represent subspeciation.

The parasitism of domestic rabbits differs from that in the wild: Zundel (1979) carried out a survey in breeding colonies in different parts of France and listed nine intestinal species. Two of the species recorded, although designated by different names, correspond to species found by us in the wild: Eimeria sp. sensu Zundel $=E$. flavescens, and E. neoleporis sensu Zundel $=E$. coecicola . His list differs from ours by the presence of E. irresidua and the absence of E. exigua and E. roobroucki. The percentages of prevalence $(\mathrm{P})$ and parasite load (PL) were approximately as follows: E. perforans: P $87 \%$, PL $37 \%$; E. media: P $55 \%$, PL $10 \%$; E. magna: P $53 \%$, PL $37 \%$; E. flavescens P $30 \%$, PL $1 \%$; E. irresidua: P $25 \%$, PL $1 \%$; E. intestinalis: P $21 \%$, PL $10 \%$; E. piriformis: P $13 \%$, PL $1 \%$; and E. coecicola: P $11 \%$, PL $10 \%$. However, contrary to what we observed with wild rabbits, the ranking of prevalence varied from one region to the other.

The predominance in breeding colonies of domestic rabbits of the three species E. perforans, E. media and E. magna has also been reported in Italy (Gallazzi 1977), England (Catchpole \& Norton, 1979), Belgium (Peeters \& Geeroms, 1981), Saudi Arabia (Kasim \& AlShawa, 1987), Nigeria (Okewole, 1990), and India (Souza et al., 1993). These species remained dominant in the industrial breeding colonies after developing resistance to robenidine.

In contrast to these observations, in the wild rabbit in its natural environment, in south-west Australia, Hobbs \& Twigg (1998) found prevalences to be very similar to ours in France: E. perforans, $84 \%$; E. flavescens, $60 \%$; E. piriformis, $50 \%$; E. exigua, $62 \%$; E. media $45 \%$; E. magna, $33 \%$; E. coecicola, $7 \%$; E. stiedai $26 \%$; and E. intestinalis, $19 \%$. The only important difference was the presence in Australia of E. irresidua (9\%) and the absence of E. roobroucki. This was not true, however, for the parasite intensities.

\section{THE BALANCE BETWEEN CONGENERIC SPECIES}

Several factors have influenced speciation of Eimeria in rabbits: a long evolutionary period, the Lagomorpha having evolved little since the Eocene and having retained their parasitic fauna, and geographical isolation together with monoxenous life cycles and oocysts which appear to be (Coudert \& Ivoré, 1973) fragile and destroyed by heat.

Rabbits are strictly herbivorous, but they are opportunistic feeders which accounts for the variability of parasite intensity from each individual. However the stability of the rank of prevalence indicates an ancient and highly stable equilibrium. 


\section{ACKNOWLEDGEMENTS}

T This study was supported by a grant from the Office National de la Chasse et de la Faune Sauvage (ONCFS). We are very grateful to F. Biady, director of CNERA for allowing our work to be carried out in the national reserves of ONCFS and to the colleagues who collected the biological material, particularly S. Avignon, G. Delacour, J.C. Gaudin, F. Bernard and G. Leray. We are much indebted to A. Roobrouck for his help in the work performed at Versailles and to S. Marchandeau for his constant help and advice throughout this study. Many thanks to John Baker and Jean-Charles Gantier for their great help.

\section{REFERENCES}

Catchpole J. \& Norton C.C. The species of Eimeria in rabbits for meat production in Britain. Parasitology, 1979, 79, 249-257.

COUdert P. \& Ivore P. Sensibilité des oocystes d'Eimeria à la température. Comptes Rendus des Journées de Recherches Avicoles et Cunicoles, 1973, 269-272.

Coudert P., Licois D. \& Drouet-Viard F. Eimeria species and strains of Rabbits, in : Biotechnology guidelines on techniques in coccidiosis research. Office for official publications of the european communities Press, 1995, 52-73.

Gallazzi D. Cyclical variations in the excretion of intestinal coccidial oocysts in the rabbit. Folia Veterinaria Latina, 1977, 7, 371-381.

GrÈs V. La coccidose des lapins de garenne en France. Thèse, parasitologie. Paris, Université Paris XII, 2001.

Gres V., Marchandeau S. \& Landau I. Description d'une nouvelle espèce d'Eimeria (Coccidia, Eimeridea) chez le lapin de garenne Oryctolagus cuniculus en France. Zoosystema, 2002, 24, 203-207.

Hobbs R.P. \& Twigg L.E. Coccidia (Eimeria spp) of wild rabbits in southwestern Australia. Australian Veterinary Journal, 1998, 76, 209-210.

Kasim A.A. \& Al-SHawa Y.R. Coccidia in rabbits (Oryctolagus cuniculus) in Saudi Arabia. International Journal for Parasitology, 1987, 17, 941-944.

Myers K. \& Gilbert N. Determination of age od wild rabbits in Australia. Journal of Wildlife Manage, 1968, 32, 841-848.

OKEWOLE P.A. Note on an epidemic of coccidiosis in domestic rabbits in the plateau and Bauchi states, Nigeria. Revue Élevage Médicale et Vétérinaire des Pays Tropicaux, 1990, 43, 343-344.

Peeters J.E. \& Geeroms R. Coccidiosis in rabbits: a field study. Research in Veterinary Science, 1981, 30, 328-334.

Souza P.E., Rajeshwari Y.B., Jagannath M.S. \& Abdul Rahman S. Rabbit coccidiosis and its treatment. Indian Veterinary and Medical Journal, 1993, 17, 157-159
Zundel E. Coccidies et coccidioses intestinales du lapin - étude bibliographique, enquête épidémiologique. Veterinary thesis, Créteil University, 1979.

Reçu le 13 juillet 2002 Accepté le 12 décembre 2002 